\title{
Development of GABAergic and Glycinergic Transmission in the Neonatal Rat Dorsal Horn
}

\author{
Mark L. Baccei and Maria Fitzgerald \\ Department of Anatomy and Developmental Biology, University College London, London WC1E 6BT, United Kingdom
}

\begin{abstract}
Cutaneous spinal sensory transmission appears to lack inhibitory control in the newborn spinal cord, but the properties of GABAergic and glycinergic synapses in the neonatal dorsal horn have not been characterized. Whole-cell patch-clamp recordings from rat superficial dorsal horn neurons in spinal cord slices at postnatal day 0 (P0) to P2, P6-P7, and P13-P14 revealed an age-dependent increase in the frequency of spontaneous IPSCs, which were abolished by the $\mathrm{GABA}_{\mathrm{A}}$ receptor $\left(\mathrm{GABA}_{\mathrm{A}} \mathrm{R}\right)$ antagonist bicuculline between $\mathrm{P} 0$ and $\mathrm{P} 7 \mathrm{but}$ not at P14. GABA $A_{A} R$-mediated miniature IPSCs (mIPSCs), but not glycinergic mIPSCs, were present at birth, and GABA mIPSCs remained more frequent than glycine mIPSCs at all ages. Sciatic nerve stimulation resulted in IPSCs with both GABAergic and glycinergic components, although a larger contribution arose from $\mathrm{GABA}_{\mathrm{A}}$ receptors at all ages. In gramicidin perforated patch-clamp recordings, exogenous GABA applications produced depolarization in $40 \%$ of neurons at P0-P2, but the reversal potential of GABA-evoked currents $\left(E_{\mathrm{GABA}}\right)$ was consistently more negative than action potential threshold at this age. By P6-P7, GABA evoked only membrane hyperpolarization. The $\mathrm{GABA}_{\mathrm{B}} \mathrm{R}$ agonist baclofen elicited an outward current in all neurons with peak amplitudes observed by P6-P7 and abolished sciatic nerve-evoked monosynaptic glutamatergic EPSCs in all groups. The results show considerable postnatal development of inhibitory processing in the dorsal horn with GABAergic mechanisms initially dominant over glycinergic events. $\mathrm{GABA}_{\mathrm{A}} \mathrm{R}$-mediated depolarizations during the first postnatal week are likely to be important for the maturation of spinal networks but do not provide a major excitatory drive to the newborn dorsal horn.
\end{abstract}

Key words: spinal cord; inhibition; baclofen; gramicidin; IPSC; patch clamp

\section{Introduction}

Cutaneous sensory processing in the postnatal period is characterized by an apparent lack of inhibition. Cutaneous flexion reflexes evoked by mechanical stimulation of the skin are exaggerated in neonatal humans, kittens, and rats (Andrews and Fitzgerald, 1994; Fitzgerald and Jennings, 1999). The cutaneous receptive fields of neonatal rat dorsal horn neurons are large at birth and decrease rapidly over the first 2 postnatal weeks (Fitzgerald, 1985; Torsney and Fitzgerald, 2002). In addition, excitation of dorsal horn neurons at postnatal day $0(\mathrm{P} 0)$ to $\mathrm{P} 3$ often results in a prolonged afterdischarge of action potentials (APs) that decreases with age (Fitzgerald, 1985). Because primary afferent inputs to the dorsal horn strengthen with postnatal age (Fitzgerald and Jennings, 1999; Baccei et al., 2003), these properties suggest that inhibitory systems in the spinal cord may be immature in the neonate. However, little is known about the properties of inhibitory synaptic transmission in the developing dorsal horn.

GABA and glycine serve as the main inhibitory neurotrans-

Received Nov. 25, 2003; revised April 2, 2004; accepted April 3, 2004.

This work was supported by Medical Research Council Grant 52378. We thank Dr. D. Billups for advice during the project, Drs. R. Bardoni, M. Baker, and J. Wood for the kind loan of equipment, and Dr. D. Attwell for helpful comments on the preparation of this manuscript.

Correspondence should be addressed to Mark Baccei, Department of Anatomy and Developmental Biology, University College London, Gower Street, London WC1E 6BT, UK. E-mail: m.baccei@ucl.ac.uk.

DOI:10.1523/JNEUROSCI.5211-03.2004

Copyright $\odot 2004$ Society for Neuroscience $\quad$ 0270-6474/04/244749-09\$15.00/0 mitters in the superficial dorsal horn of the adult spinal cord (Todd and Spike, 1993) through the activation of ligand-gated anion channels $\left[\mathrm{Cl}^{-}\right.$-permeable $\mathrm{GABA}_{\mathrm{A}}$ receptors $\left(\mathrm{GABA}_{\mathrm{A}} \mathrm{Rs}\right)$, $\mathrm{GABA}_{\mathrm{C}} \mathrm{Rs}$, or glycinergic receptors (GlyRs)] or G-proteincoupled $\mathrm{GABA}_{\mathrm{B}}$ receptors (Bormann, 1988). A combination of $\mathrm{GABA}_{\mathrm{A}} \mathrm{R}$ and GlyR antagonists are required to block primary afferent-evoked IPSCs in adult substantia gelatinosa (lamina II) neurons (Moore et al., 2002). At present, it is unknown whether GABAergic and glycinergic systems are both functional during early postnatal life. An absence of one or several components of synaptic inhibition could contribute to the enlarged receptive fields and afterdischarges seen in neonatal dorsal horn neurons.

These properties could also be potentially explained by excitation of immature dorsal horn neurons by GABA or glycine. In a variety of CNS regions (including the hippocampus, neocortex, and hypothalamus), high intracellular chloride concentrations $\left(\left[\mathrm{Cl}^{-}\right]_{\mathrm{i}}\right)$ found in neonatal neurons result in membrane depolarization after $\mathrm{GABA}_{\mathrm{A}} \mathrm{R}$ or GlyR activation (Ben Ari, 2002; Owens and Kriegstein, 2002), sometimes resulting in action potential discharge (Ben Ari et al., 1989; Chen et al., 1996; Gao and van den Pol, 2001). In cultured embryonic dorsal horn neurons, GABA or glycine application causes depolarization and a rise in intracellular $\left[\mathrm{Ca}^{2+}\right]$, which progressively decline over time in culture (Reichling et al., 1994; Wang et al., 1994). However, it is still unclear whether GABA-mediated depolarizations persist in the intact superficial dorsal horn throughout the first 2 postnatal weeks and are sufficient to elicit action potentials. 
The present study characterizes the properties of GABAergic and glycinergic signaling in the immature superficial dorsal horn, an area known to be crucial for the processing of painful stimuli, to determine whether the mechanisms of synaptic inhibition that dominate in the adult spinal cord are also functional at early postnatal ages.

\section{Materials and Methods}

All experimental procedures were performed according to the United Kingdom Animals (Scientific Procedures) Act of 1986.

Preparation of spinal cord slices. Neonatal Sprague Dawley pups (P0P14) were humanely killed by an overdose of halothane (5\% in medical oxygen) and decapitated. The spinal column was quickly removed and placed in an ice-cold dissection solution containing the following (in mM): $125 \mathrm{NaCl}, 2.5 \mathrm{KCl}, 25 \mathrm{NaHCO}_{3}, 1.0 \mathrm{NaH}_{2} \mathrm{PO}_{4}, 6 \mathrm{MgCl}_{2}, 0.5 \mathrm{CaCl}_{2}$, and 25 glucose (continuously bubbled with $95 \% \mathrm{O}_{2}-5 \% \mathrm{CO}_{2}$ ). After a ventral laminectomy was performed, the spinal cord was removed and immersed in low-melting-point agarose (3\% in above dissection solution; Invitrogen, Paisley, UK) at $37^{\circ} \mathrm{C}$. After cooling, the block of agarose was glued to the chamber of a Vibroslice tissue slicer (HA-752; Campden Instruments, Leicester, UK), and $400 \mu \mathrm{m}$ sagittal slices were cut from the lumbar region. For experiments involving the recording of IPSCs evoked by primary afferent stimulation, the sciatic nerve and the L4 and L5 DRGs were exposed after the ventral laminectomy and removed with the spinal cord. Subsequently, using a modified Vibroslice, a sagittal slice $(400-600 \mu \mathrm{m})$ was cut that preserves the entire L4-L5 dorsal root entry zone with the L4 and L5 DRGs and sciatic nerve attached. The slices were transferred to a chamber filled with oxygenated dissection solution and allowed to recover for 1.5-2 $\mathrm{hr}$ at room temperature.

Patch-clamp recordings. After recovery, slices were transferred to a submersion-type recording chamber (RC-22; Warner Instruments, Hamden, CT) and mounted on the stage of an upright microscope (Axioskop 2; Zeiss, Welwyn Garden City, UK). The slices were continually perfused at room temperature with oxygenated artificial CSF (aCSF) solution containing the following (in $\mathrm{mm}$ ): $125 \mathrm{NaCl}, 2.5 \mathrm{KCl}, 25$ $\mathrm{NaHCO}_{3}, 1.0 \mathrm{NaH}_{2} \mathrm{PO}_{4}, 1.0 \mathrm{MgCl}_{2}, 2.0 \mathrm{CaCl}_{2}$, and 25 glucose (at a rate of $1-3 \mathrm{ml} / \mathrm{min}$ ).

Patch electrodes were constructed from thin-walled single-filamented borosilicate glass $(1.5 \mathrm{~mm}$ outer diameter; World Precision Instruments, Hertfordshire, UK) using a two-stage vertical microelectrode puller (PP830 ; Narishige, London, UK). Pipette resistances ranged from 5 to $7 \mathrm{M} \Omega$, and seal resistances were $>1 \mathrm{G} \Omega$. For voltage-clamp experiments in the whole-cell recording configuration, electrodes were filled with a solution containing the following (in mM): $130 \mathrm{Cs}$-gluconate, $10 \mathrm{CsCl}, 10 \mathrm{HEPES}$, $11 \mathrm{EGTA}, 1.0 \mathrm{CaCl}_{2}$, and 2.0 MgATP, pH 7.2 (305 mOsm). Currentclamp experiments used an electrode solution containing the following (in $\mathrm{mM}$ ): $130 \mathrm{~K}$-gluconate, $10 \mathrm{KCl}, 10 \mathrm{HEPES}, 1.0 \mathrm{EGTA}, 0.1 \mathrm{CaCl}_{2}$, and 2.0 MgATP, pH 7.2 (305 mOsm).

For perforated patch-clamp experiments, gramicidin (Sigma, Dorset, UK) was dissolved at $2.5 \mathrm{mg} / \mathrm{ml}$ in DMSO and stored at $-20^{\circ} \mathrm{C}$ for up to 1 week. Electrode tips were filled with the above K-gluconate solution and subsequently backfilled with gramicidin diluted in the same solution to a final concentration of $25 \mu \mathrm{g} / \mathrm{ml}$. Access resistance $\left(R_{\text {acc }}\right)$ was carefully monitored during perforation and throughout the experiment, and any neurons in which a sudden drop in $R_{\text {acc }}$ occurred were discarded. In voltage-clamp experiments to measure the reversal potential for GABAevoked currents $\left(E_{\mathrm{GABA}}\right)$, holding potentials were corrected for voltage errors across uncompensated series resistance according to $V_{\text {corrected }}=$ $V_{\text {command }}-I R_{\text {acc }}$. Membrane voltages were also adjusted for liquid junction potentials (approximately $-14 \mathrm{mV}$ ) calculated using JPCalc software (P. Barry, University of New South Wales, Sydney, Australia; modified for Axon Instruments, Union City, CA).

Dorsal horn neurons were visualized with infrared-differential interference contrast, and patch-clamp recordings were obtained using a Multiclamp 700A amplifier (Axon Instruments). Spontaneous IPSCs (sIPSCs) were recorded at a holding potential of $0 \mathrm{mV}$, thus minimizing the contribution of NMDA and AMPA/kainate receptor-mediated events (Yoshimura and Nishi, 1993). Miniature IPSCs (mIPSCs) were isolated via the application of $500 \mathrm{~nm}$ tetrodotoxin (TTX) with $20 \mu \mathrm{M}$ $\mathrm{D}(-)$ 2-amino-5-phosphonovaleric acid [D(-)AP-5] and $10 \mu \mathrm{M}$ 1,2,3,4tetrahydro-6-nitro-2,3-dioxo-benzo(f)quinoxaline-7-sulfonamide (NBQX) added to block currents through ionotropic glutamate receptors. Bicuculline methiodide $(10 \mu \mathrm{M})$ or strychnine $(0.5 \mu \mathrm{M})$ was added to the above solution to isolate GlyR-mediated or $\mathrm{GABA}_{\mathrm{A}} \mathrm{R}$-mediated mIPSCs, respectively. IPSCs were evoked via electrical stimulation of the sciatic nerve with a suction electrode connected to a constant-current stimulator (NeuroLog system; Digitimer, Hertfordshire, UK).

Postsynaptic GABA $\mathrm{B}_{\mathrm{B}}$ effects were investigated using the above $\mathrm{K}^{+}$gluconate solution with $0.3 \mathrm{~mm} \mathrm{Na} \mathrm{Na}_{3} \mathrm{GTP}$ added to avoid depletion of intracellular GTP. Baclofen was bath applied in the presence of $500 \mathrm{~nm}$ TTX, $20 \mu \mathrm{M} \mathrm{D}(-)$ AP-5, $10 \mu \mathrm{M}$ NBQX, $10 \mu \mathrm{M}$ bicuculline, and $0.5 \mu \mathrm{M}$ strychnine.

Currents were filtered at $4-6 \mathrm{kHz}$ through a $-3 \mathrm{~dB}$, four-pole lowpass Bessell filter, digitally sampled at $20 \mathrm{kHz}$, and stored on a personal computer (Viglen, Middlesex, UK) using a commercially available data acquisition system (Digidata 1322A with pClamp 8.0 software; Axon Instruments).

Drugs. GABA, (-)-bicuculline methiodide, strychnine, D(-)AP-5, gramicidin $\mathrm{D}, \mathrm{R}(+)$-baclofen hydrochloride, GTP $\left(\mathrm{Na}_{3} \mathrm{GTP}\right)$, and guanosine $5^{\prime}$-O-(2-thiodiphosphate) (GDP $\beta S$ ) were purchased from Sigma (Dorset, UK). TTX, NBQX, and CGP 55845 [(2S)-3-\{[(1S)-1(3,4-dichlorophenyl)ethyl] amino-2-hydroxypropyl)(phenylmethyl) phosphinic acid] were purchased from Tocris Cookson (Bristol, UK). All drugs except GABA were bath applied at $1-3 \mathrm{ml} / \mathrm{min}$. GABA (1 mM) was pressure ejected (50-200 msec, 5-6 psi) through a patch electrode near the recorded neuron using the Picospritzer application system (General Valve Operation; Parker Hannifin, Fairfield, NJ).

Data analysis and statistics. Data were analyzed via visual inspection using Mini Analysis (version 5.4.1; Synaptosoft, Decatur, GA) and Clampfit (Axon Instruments) software. The threshold for mIPSC and sIPSC detection was set at twice the mean amplitude of the background noise. Multiphasic IPSCs evoked by primary afferent stimulation were quantified by measuring the area under the curve (AUC) for a $1 \mathrm{sec}$ period from the IPSC onset. Because it has previously been observed that IPSC (or EPSC) frequencies often fail to exhibit a normal distribution in newborn dorsal horn neurons, we used nonparametric statistical tests to determine whether significant differences in IPSC frequency existed between various groups (Wilcoxon matched-pairs or Mann-Whitney tests for two groups, Kruskal-Wallis test for more than two groups; Prism 3.0 software; GraphPad Software, San Diego, CA). Nonparametric tests were also used in cases in which the number of observations was insufficient $(n<24)$ to definitively conclude that data were distributed in a Gaussian manner. Data are expressed as means \pm SEM.

\section{Results}

Patch-clamp recordings were obtained from 306 neurons in the neonatal rat dorsal horn from the following three age groups: P0-P2 $(n=131), \mathrm{P} 6-\mathrm{P} 7(n=91)$, and P13-P14 $(n=84)$. All neurons were located in the superficial dorsal horn (laminas I-II) as judged by visual inspection. Because the sampled neurons were located at an average distance (measured from the dorsal white matter) of $60.1 \pm 1.4 \mu \mathrm{m}$ at $\mathrm{P} 0-\mathrm{P} 2,76.1 \pm 2.3 \mu \mathrm{m}$ at P6-P7, and $93.9 \pm 2.7 \mu \mathrm{m}$ at P13-P14, it seems likely that the majority of these neurons were located in lamina II.

\section{Spontaneous and miniature IPSCs in the superficial dorsal horn are mediated by $\mathrm{GABA}_{\mathrm{A}}$ receptors during the first postnatal week}

In the whole-cell patch-clamp experiments of the present study, sIPSCs are observed as transient outward currents from a holding potential of $0 \mathrm{mV}$ (Fig. $1 \mathrm{~A}$ ). The frequency of sIPSCs recorded in aCSF increased significantly over the first 2 postnatal weeks (Fig. $1 B)$ from $0.22 \pm 0.08 \mathrm{~Hz}(n=35)$ at $\mathrm{P} 0-\mathrm{P} 1$ to $0.95 \pm 0.28 \mathrm{~Hz}$ $(n=31)$ by P6-P7 $(p<0.001$; Kruskal-Wallis test $)$ and $2.09 \pm$ $0.58 \mathrm{~Hz}(n=29)$ by P13-P14 $(p<0.001)$. In contrast, the size of 
A

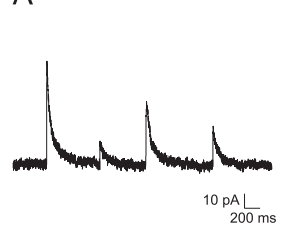

B

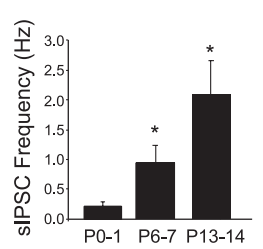

C

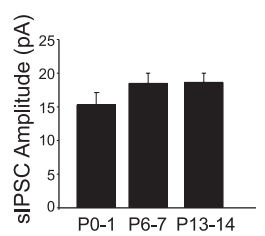

Figure 1. SIPSCS in the superficial dorsal horn as a function of postnatal age. $A$, IPSCS are evident as transient outward currents from a holding potential of $0 \mathrm{mV}$. B, sIPSC frequency increases significantly with postnatal age ${ }^{*} p<0.001$ compared with $\mathrm{PO}-\mathrm{P} 1$; Kruskal-Wallis test). C, The mean sIPSC amplitude was not significantly different between groups.

the sIPSCs did not change with advancing postnatal age, with mean amplitudes of $15.30 \pm 1.79 \mathrm{pA}(n=26)$ at $\mathrm{P} 0-\mathrm{P} 1,18.52 \pm$ $1.42 \mathrm{pA}(n=29)$ at $\mathrm{P} 6-\mathrm{P} 7$, and $18.63 \pm 1.63 \mathrm{pA}(n=29)$ at P13-P14 ( $p>0.20$; one-way ANOVA) (Fig. $1 C)$.

To determine the relative contribution of $\mathrm{GABA}_{\mathrm{A}} \mathrm{Rs}$ and GlyRs to the observed sIPSC frequency, the selective $G_{A B A} R$ antagonist $(-)$ bicuculline methiodide $(10 \mu \mathrm{M})$ was added to the bath solution. During the first postnatal week, spontaneous activity appeared to be mediated predominantly by $\mathrm{GABA}_{\mathrm{A}} \mathrm{Rs}$ because bicuculline significantly reduced the overall sIPSC frequency by $89.3 \pm 6.8 \%$ at $\mathrm{P} 0-\mathrm{P} 1$ (from $0.31 \pm 0.11$ to $0.05 \pm 0.04$ $\mathrm{Hz} ; n=11 ; p<0.005$; Wilcoxon matched-pairs test), with a total abolition of sIPSCs (Fig. 2A) observed in 6 of the 11 neurons sampled at this age. A recovery in sIPSC frequency was observed during washout of bicuculline (data not shown), suggesting that a time-dependent rundown of synaptic currents cannot explain the decrease in sIPSC frequency during bicuculline application. At P6-P7, the vast majority of IPSCs were still mediated by $\mathrm{GABA}_{\mathrm{A}}$ Rs because bicuculline decreased the mean sIPSC frequency by $88.5 \pm 5.5 \%$ (from $0.83 \pm 0.18$ to $0.07 \pm 0.03 \mathrm{~Hz} ; n=$ $15 ; p<0.0001)$. By this age, most neurons did exhibit both $\mathrm{GABA}_{\mathrm{A}} \mathrm{R}$ - and GlyR-mediated sIPSCs ( 3 of 15 cells showed a complete absence of sIPSCs in bicuculline). In contrast, bicuculline application did not significantly affect sIPSC frequency in the overall population of P13-P14 neurons sampled (aCSF, $1.82 \pm$ $0.78 \mathrm{~Hz}$; bicuculline, $1.44 \pm 0.55 \mathrm{~Hz} ; n=18 ; p>0.20$; Wilcoxon test). This seems to reflect the variability in bicuculline effects on individual dorsal horn neurons at this age rather than a disappearance of $\mathrm{GABA}_{\mathrm{A}} \mathrm{R}$ activity. Bicuculline treatment significantly decreased the sIPSC frequency in 6 of 18 cells at P13-P14 $(p<$ 0.05 ; Kolmogorov-Smirnov two-sample test), with complete abolition of sIPSCs observed in only two of these neurons, suggesting that most P13-P14 neurons possessed both $\mathrm{GABA}_{\mathrm{A}} \mathrm{R}$ - and GlyR-mediated sIPSCs. Meanwhile, bicuculline significantly elevated the overall sIPSC frequency in 4 of 18 neurons by an average of $165.7 \pm 102.5 \%$ (from $1.79 \pm 0.99$ to $3.09 \pm 1.20 \mathrm{~Hz} ; n=4$ ), which may result from disinhibition of spinal interneurons. The mean frequency of sIPSCs observed in the presence of bicuculline at different postnatal ages is illustrated in Figure $2 \mathrm{~B}$ and demonstrates that spontaneous glycine-mediated currents are rare in the first postnatal week. This is supported by the finding that sIPSC frequency in the presence of the selective GlyR antagonist strychnine $(0.5 \mu \mathrm{M})$ was $93.1 \pm 15.1 \%$ of control in P0-P7 neurons (aCSF, $0.25 \pm 0.07 \mathrm{~Hz}$; strychnine, $0.23 \pm 0.06 \mathrm{~Hz} ; n=13 ; p>$ 0.30; Wilcoxon test) (Fig. 2C). The presence of functional GlyRs in the membrane was confirmed by pressure ejections of exogenous glycine $(1 \mathrm{mM}, 200 \mathrm{msec})$ near the recorded cell in the presence of bicuculline $(10 \mu \mathrm{M})$. Glycine application resulted in an outward current in all cells tested $(n=18)$ (Fig. $2 D)$, with a mean amplitude of $417.0 \pm 42.4 \mathrm{pA}$ at a holding potential of 0

$\mathrm{mV}$. Pretreatment with strychnine $(5 \mu \mathrm{M})$ abolished the glycineevoked currents ( $n=6$; data not shown).

The predominance of $\mathrm{GABA}_{\mathrm{A}} \mathrm{R}$-mediated events during the first postnatal week is also illustrated by the recording of mIPSCs in $500 \mathrm{nM}$ TTX with $20 \mu \mathrm{M} \mathrm{D}(-) \mathrm{AP}-5$ and $10 \mu \mathrm{M}$ NBQX added to block currents through ionotropic glutamate receptors. The frequency of TTX-resistant mIPSCs was significantly lower than the rate of sIPSCs at all ages tested (compare Figs. $1 B, 3 A$ ), suggesting a role for presynaptic action potentials in sIPSC generation. Importantly, no glycinergic mIPSCs (isolated via the bath application of $10 \mu \mathrm{M}$ bicuculline) were observed in neurons sampled at P0-P1 $(n=14)$ (Fig. 3A). In addition, bath application of ruthenium red $(100 \mu \mathrm{M})$, known to enhance mIPSC frequency via calcium-independent mechanisms (Trudeau et al., 1996; Keller et al., 2001), failed to reveal Gly mIPSCs in 7 of 10 neurons examined at P0-P1 (data not shown). Meanwhile, GABA mIPSCs (recorded in the presence of $0.5 \mu \mathrm{M}$ strychnine) were observed at a rate of $0.005 \pm 0.001 \mathrm{~Hz}$ at this age (Fig. 3A). Gly mIPSCs were sporadically observed across the population of $\mathrm{P} 6-\mathrm{P} 7$ neurons $(0.004 \pm 0.003 \mathrm{~Hz} ; n=11)$ but were absent in 8 of the 11 neurons examined. The frequency of GABA mIPSCs increased significantly over the first 2 postnatal weeks to $0.14 \pm 0.02 \mathrm{~Hz}(n=13)$ at P6-P7 and $0.17 \pm 0.12 \mathrm{~Hz}(n=14)$ at P13-P14 $(p<0.001$; Kruskal-Wallis test). As depicted in Figure $3 A$, the frequency of Gly mIPSCs remained low at P13-P14, with a mean rate of $0.011 \pm 0.008 \mathrm{~Hz}(n=10)$, and was significantly lower than the GABA mIPSC frequency at all ages tested ( $p<0.001$; MannWhitney test).

The size of GABA mIPSCs was significantly lower at birth than later postnatal ages, with mean amplitudes of $5.41 \pm 0.62 \mathrm{pA}(n=$ $7)$ at $\mathrm{P} 0-\mathrm{P} 1,12.51 \pm 2.07 \mathrm{pA}(n=13)$ at $\mathrm{P} 6-\mathrm{P} 7(p<0.001$; Kruskal-Wallis test), and $9.03 \pm 0.49 \mathrm{pA}(n=14)$ at P13-P14 $(p<0.01)$. In the few neurons that displayed Gly mIPSCs in the P6-P7 and P13-P14 groups, the size of the Gly mIPSCs were significantly smaller than GABA mIPSCs, with average amplitudes of $5.76 \pm 0.46 \mathrm{pA}$ at P6-P7 $(n=3$; $p<0.05$; MannWhitney test $)$ and $5.11 \pm 0.33 \mathrm{pA}$ at P13-P14 $(n=5 ; p<0.005)$ (Fig. 3B).

\section{Pharmacological properties of primary afferent-evoked IPSCs in the neonatal dorsal horn}

Electrical stimulation of the sciatic nerve at C-fiber intensity (1 $\mathrm{mA}, 1 \mathrm{msec}$ at $0.033 \mathrm{~Hz}$ ) in aCSF evoked multiphasic IPSCs in neonatal dorsal horn neurons of all ages from a holding potential of $0 \mathrm{mV}$. Bath application of bicuculline $(10 \mu \mathrm{M})$ led to a substantial reduction in the composite IPSC, and the subsequent addition of strychnine $(0.5 \mu \mathrm{M})$ abolished the outward current (Fig. $4 A$ ), confirming the selective involvement of $\mathrm{GABA}_{\mathrm{A}} \mathrm{Rs}$ and GlyRs in the observed response. To quantify the respective contributions of the different receptors to the evoked IPSC, electronic subtraction was used to isolate the bicuculline-sensitive and strychnine-sensitive components of the IPSC. For each component, the AUC was calculated for a $1 \mathrm{sec}$ period after the onset of the IPSC as a measurement of the net movement of charge through the receptors.

As documented in Figure $4 B$, the $\mathrm{GABA}_{\mathrm{A}} \mathrm{R}$-mediated component of the evoked IPSC significantly increased during the first postnatal week, because the mean AUC for the bicucullinesensitive currents was $17.26 \pm 4.14 \mathrm{nA} / \mathrm{msec}(n=15)$ at P2, $97.78 \pm 21.62 \mathrm{nA} / \mathrm{msec}$ by P6-P7 $(n=17 ; p<0.001$; KruskalWallis test), and $73.50 \pm 15.11 \mathrm{nA} / \mathrm{msec}$ at P13-P14 $(n=16 ; p<$ 0.01 ). The GlyR-mediated component also increased with postnatal age, with mean AUCs of $2.96 \pm 0.81 \mathrm{nA} / \mathrm{msec}$ at P2 $(n=$ 
15), $14.92 \pm 4.30 \mathrm{nA} / \mathrm{msec}$ at P6-P7 $(n=$ $17)$, and $24.22 \pm 5.71 \mathrm{nA} / \mathrm{msec}(n=16)$ at P13-P14 $(p<0.05$ compared with P2 group). In addition, the GlyR component of the evoked IPSC was significantly smaller than the $\mathrm{GABA}_{\mathrm{A}} \mathrm{R}$ component at all ages tested ( $p<0.005$; Mann-Whitney test) (Fig. $4 B$ ), further supporting the dominant role of $\mathrm{GABA}_{\mathrm{A}}$ Rs in spontaneous and evoked neurotransmission in the neonatal dorsal horn.

$\mathrm{GABA}_{\mathrm{A}} \mathrm{R}$ activation causes subthreshold depolarizations in dorsal horn neurons with intact $\left[\mathrm{Cl}^{-}\right]_{\mathrm{i}}$ during the first postnatal week

The effect of $\mathrm{GABA}_{\mathrm{A}} \mathrm{R}$ activation on the
A

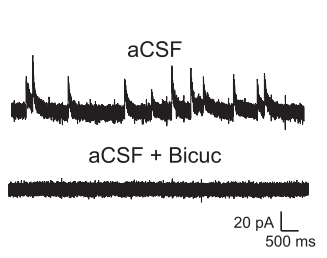

$\mathrm{B}$

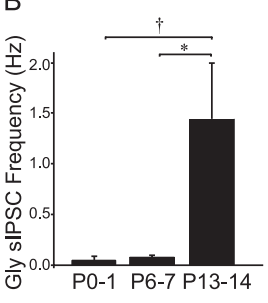

C

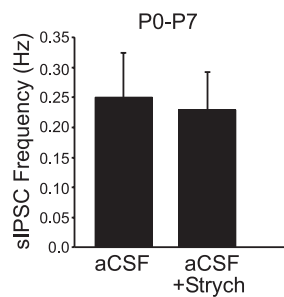

D

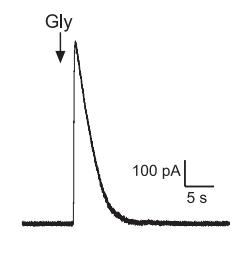

Figure 2. SIPSCs are predominantly mediated by $G A B A_{A}$ Rs during the first postnatal week. $A$, Abolition of sIPSCs by the $G A B A_{A} R$ antagonist bicuculline (10 $\mu \mathrm{m}$; Bicuc) in a P7 neuron. $B$, Frequency of glycinergic sIPSCs (isolated with $10 \mu \mathrm{m}$ bicuculline) increases during the second postnatal week $\left({ }^{\dagger} p<0.001 ;{ }^{*} p<0.05\right.$; Kruskal-Wallis test). C, Application of the GlyR antagonist strychnine $(0.5 \mu \mathrm{m}$; Strych) does not significantly affect s IPSC frequency in P0 -P7 dorsal horn neurons $(n=13)$, consistent with a dominant role for $G A B A_{A} R s$ during the first week. D, Exogenous applications of glycine $(1 \mathrm{~mm})$ elicited outward currents in all cells examined at PO $-\mathrm{P7}(n=18)$.
A

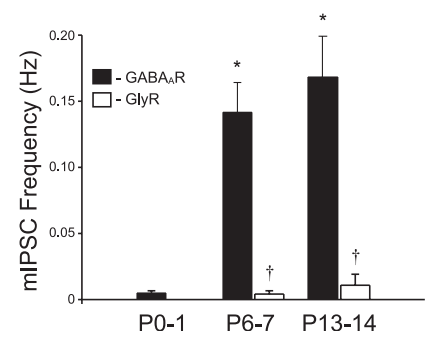

B

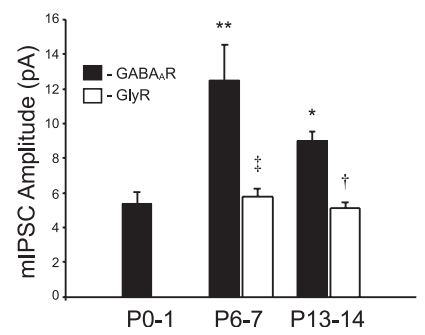

Figure 3. GlyR- and $\mathrm{GABA}_{\mathrm{A}} \mathrm{R}$-mediated mIPSCs in the $\mathrm{P} 0-\mathrm{P} 14$ dorsal horn. $A$, Frequency of $\mathrm{GABA}_{\mathrm{A}} \mathrm{R}$ mIPSCs increases with postnatal age ${ }^{*} p<0.001$ compared with P0 $-\mathrm{P} 1$; KruskalWallis test). GlyR mIPSCs were not observed in any of the P0-P1 neurons tested $(n=14)$ but were observed by the end of the first postnatal week at a significantly lower rate than $G A B A_{A} R$ events $\left({ }^{\dagger} p<0.001\right.$; Mann-Whitney test). $B$, Mean mIPSC amplitudes at different postnatal ages $\left({ }^{*} p<0.01,{ }^{* *} p<0.001\right.$ compared with P0 P1 with Kruskal-Wallis test; ${ }^{\dagger} p<0.05$, ${ }^{\ddagger} p<0.005$ compared with GABA mIPSC amplitude at given age with Mann-Whitney test).
A

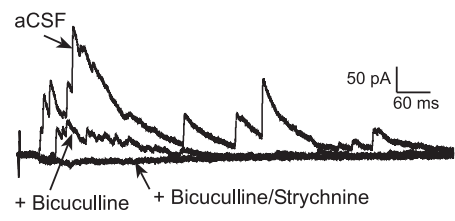

B

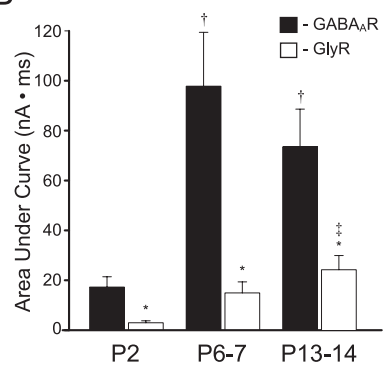

Figure 4. Primary afferent-evoked IPSCs in the neonatal superficial dorsal horn. $A$, Multiphasic IPSCs were evoked from a holding potential of $0 \mathrm{mV}$ via electrical stimulation of the sciatic nerve $(1 \mathrm{~mA}, 1 \mathrm{msec}, 0.033 \mathrm{~Hz}$ ) and dissected into its composite subtypes with selective $G A B A_{A} R$ and GlyR antagonists. For each cell, the areas under the bicuculline- and strychninesensitive waveforms were calculated for a 1 sec period from the onset of the IPSC. $B$, Average

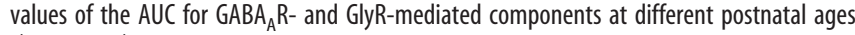
$\left({ }^{\dagger} p<0.01,{ }^{\ddagger} p<0.05\right.$ compared with P2 with Kruskal-Wallis test; ${ }^{*} p<0.05$ compared with $\mathrm{GABA}_{\mathrm{A}} \mathrm{R}$ with Mann-Whitney test).

dialyzed with a high $\left[\mathrm{Cl}^{-}\right]_{\mathrm{i}}$ solution $(150 \mathrm{~mm} \mathrm{KCl}$ and $10 \mathrm{~mm}$ HEPES) in the whole-cell recording configuration, identical GABA applications $(1 \mathrm{~mm}, 200 \mathrm{msec})$ from $V_{\text {rest }}$ led to depolarization and AP discharge in all cells examined (data not shown), demonstrating that the ejection parameters produced sufficient concentrations of GABA at the recorded neuron to evoke APs if $E_{\mathrm{Cl}}$ was significantly more positive than the AP threshold (i.e., $E_{\mathrm{Cl}}$ of $\sim 0 \mathrm{mV})$. 

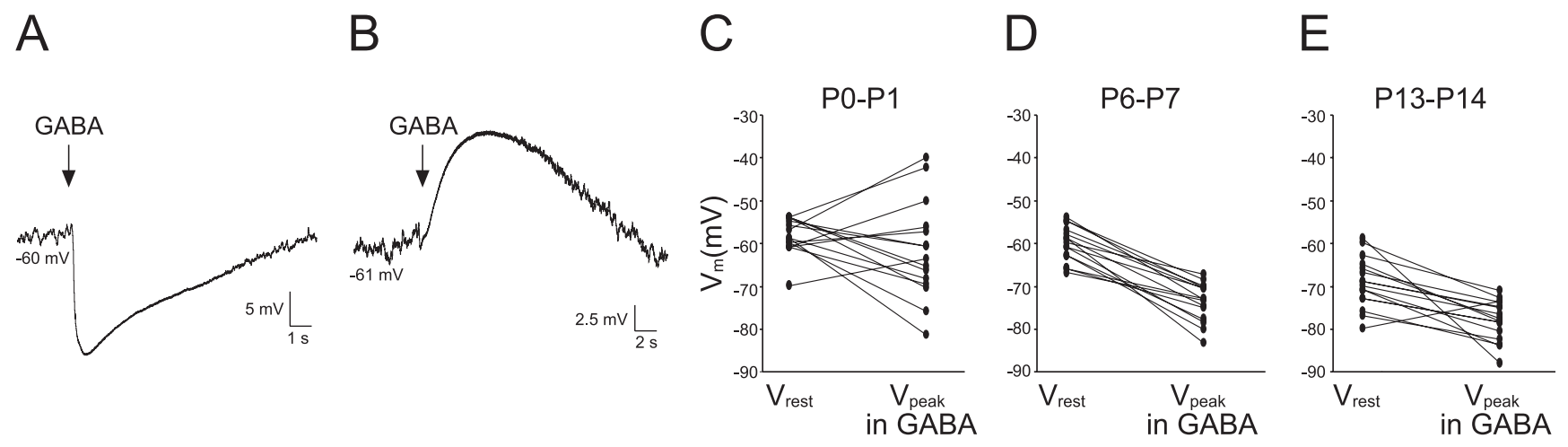

Figure 5. Effect of $\mathrm{GABA}$ on $V_{\mathrm{m}}$ of neonatal dorsal horn neurons with intact $\left[\mathrm{Cl}^{-}\right]_{\mathrm{i}} \cdot A$, Perforated patch-clamp recording showing example of hyperpolarization in response to $\mathrm{GABA}$ application $(1 \mathrm{~mm}, 200 \mathrm{msec})$ in a $\mathrm{PO}$ neuron at its resting membrane potential. $B, \mathrm{GABA}$ application results in membrane depolarization but no action potential discharge in a different $\mathrm{PO}$ neuron. $C-E$, Plots depicting the response to GABA in individual neurons at different ages. $V_{\text {rest }}$, Resting membrane potential of the cell at the time of GABA application; $V_{\text {peak }}$ in GABA, membrane voltage at the peak of the GABA response in the same neuron. There was a significant difference in the distribution of depolarizing versus hyperpolarizing responses across the different age groups ( $p<0.01 ; \chi^{2}$ test).

A

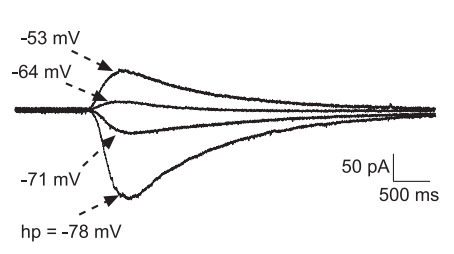

B

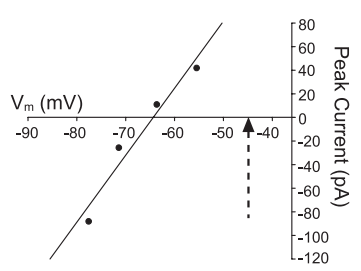

Figure 6. Comparison of $E_{\mathrm{GABA}}$ and action potential threshold in newborn dorsal horn neurons. A, Perforated patch-clamp recording showing currents evoked by GABA application (1 mM, $200 \mathrm{msec}$ ) from different holding potentials (hp). Reported holding potentials have been corrected for errors attributable to uncompensated series resistance. $B$, Current versus voltage plot for the same neuron illustrated in $A$ showing an $E_{\mathrm{GABA}}$ of $-64.4 \mathrm{mV}$ as measured by linear regression analysis $\left(r^{2}=0.95\right)$. The dotted arrow identifies the AP threshold in the same neuron. $C$, Average values for $E_{\mathrm{GABA}}$ and AP threshold in the sampled population of P0-P1 dorsal horn neurons $(n=11)$. $E_{\mathrm{GABA}}$ was more negative than AP threshold in all cells examined.

In the six neurons that depolarized in response to GABA at P0-P1 (Fig. $5 B, C$ ), the activation of $\mathrm{GABA}_{\mathrm{A}}$ Rs will also produce significant shunting of the membrane that may prevent the firing of APs during the slow depolarizations, even if $E_{\mathrm{Cl}}$ values were located above AP threshold. To address this possibility, we measured $E_{\mathrm{GABA}}$ under perforated patch-clamp conditions (Fig. $6 A, B)$ in an additional group of P0-P1 neurons. Meanwhile, APs were elicited by intracellular current injections from $V_{\mathrm{m}}$ of -60 to $-65 \mathrm{mV}$ in the same cells, and the AP threshold was measured to allow for a direct comparison of $E_{\mathrm{GABA}}$ and $\mathrm{AP}$ threshold in individual neurons (Fig. $6 B$ ). $E_{\mathrm{GABA}}$ was located at more negative membrane potentials than the AP threshold in all cells examined at this age $(n=11)$. As illustrated in Figure $6 C$, the average value of $E_{\mathrm{GABA}}$ was $-65.3 \pm 2.1 \mathrm{mV}$ at $\mathrm{P} 0-\mathrm{P} 1$, which was significantly lower than the mean AP threshold in the same neurons $(-44.6 \pm$ $1.2 \mathrm{mV} ; n=11 ; p=0.001$; Wilcoxon matched-pairs test). This strongly suggests that the absence of GABA-evoked APs in the current-clamp experiments results from the relationship between $E_{\mathrm{GABA}}$ and $\mathrm{AP}$ threshold rather than the shunting action of the $\mathrm{GABA}_{\mathrm{A}} \mathrm{R}$ conductance.

\section{Presynaptic and postsynaptic $\mathrm{GABA}_{\mathrm{B}} \mathrm{R}$ effects in the neonatal dorsal horn}

To examine the development of presynaptic inhibition by the $\mathrm{GABA}_{\mathrm{B}}$ receptor in the superficial dorsal horn, monosynaptic glutamatergic EPSCs were elicited in neurons (at a holding potential of $-60 \mathrm{mV}$ in the whole-cell configuration) via electrical
C

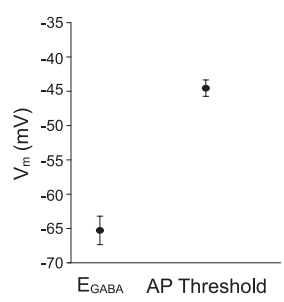

stimulation of the sciatic nerve $(1.5 \times$ threshold at $0.033 \mathrm{~Hz}$ ). EPSCs were classified as monosynaptic on the basis of stable latencies and an absence of failures in response to stimulation at $10 \mathrm{~Hz}$. After observing a stable baseline of peak current amplitude, the selective $\mathrm{GABA}_{\mathrm{B}} \mathrm{R}$ agonist $\mathrm{R}(+)$-baclofen hydrochloride $(10 \mu \mathrm{M})$ was bath applied, and its effects on EPSC amplitude were subsequently measured and expressed as a percentage inhibition of the mean amplitude seen in the predrug trials. In these experiments, postsynaptic effects of $\mathrm{GABA}_{\mathrm{B}} \mathrm{R}$ activation were excluded by the use of a cesium-based electrode solution, which prevents current efflux through G-protein-coupled inwardly rectifying $\mathrm{K}^{+}$channels (GIRKs), and the inclusion of the nonhydrolyzable GDP analog GDP $\beta$ S in the electrode solution, which blocks the activation of G-proteins by the $\mathrm{GABA}_{\mathrm{B}}$ receptor. As demonstrated in Figure $7 C$, activation of presynaptic $\mathrm{GABA}_{\mathrm{B}}$ Rs abolishes primary afferent neurotransmission in the dorsal horn from the first days of postnatal life, because the mean EPSC amplitude was reduced by $93.4 \pm 2.7 \%$ $(n=8)$ at $\mathrm{P} 2,96.0 \pm 1.3 \%(n=5)$ at $\mathrm{P} 6-\mathrm{P} 7$, and $94.3 \pm 1.84 \%$ $(n=7)$ by P13-P14. An example of the block of primary afferentevoked EPSCs by baclofen is illustrated in Figure 7A. The effects of baclofen on the evoked EPSCs were abolished by previous application of the $\mathrm{GABA}_{\mathrm{B}} \mathrm{R}$ antagonist CGP 55845 (at $2 \mu \mathrm{M}$ ), confirming the role of $\mathrm{GABA}_{\mathrm{B}} \mathrm{Rs}$ in the observed response (Fig. $7 B)$. Bath application of CGP $55845(2 \mu \mathrm{M})$ alone did not significantly affect the amplitude of the evoked EPSCs ( $n=3$; data not shown), suggesting an absence of tonic activation of $G_{A B A}$ Rs on primary afferent terminals under our experimental conditions.

The lack of postsynaptic $\mathrm{GABA}_{B} \mathrm{R}$ activation in these experiments was verified by measuring the effect of baclofen on mEPSCs recorded under the above conditions. In the presence of 500 nM TTX, baclofen significantly reduced the mEPSC frequency in a population of $\mathrm{P} 2-\mathrm{P} 14$ neurons from $0.45 \pm 0.09$ to $0.26 \pm 0.06$ $\mathrm{Hz}(n=18 ; p<0.005$; Wilcoxon matched-pairs test). In contrast, Figure $7 D$ demonstrates that mEPSC amplitude was not significantly altered by baclofen (TTX, $16.29 \pm 2.13$ pA; baclofen, $15.61 \pm 2.06 \mathrm{pA} ; n=17 ; p>0.40$; paired $t$ test). The observed decrease in the frequency of mEPSCs in the presence of baclofen 

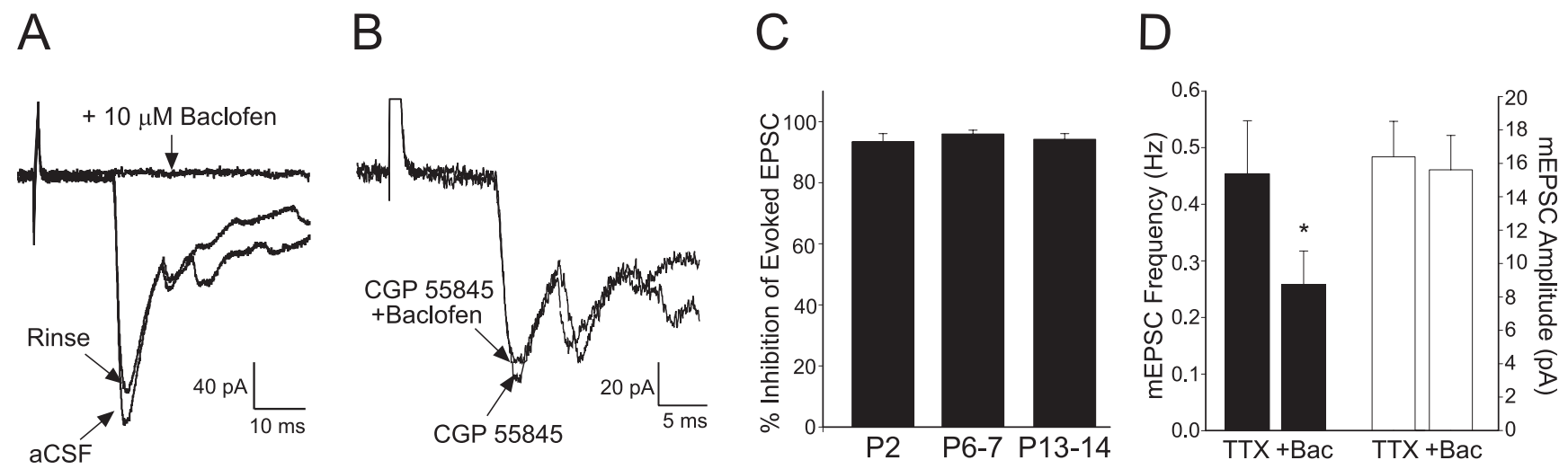

Figure 7. Potent modulation of primary afferent-evoked inputs to the superficial dorsal horn by the $G A B A_{B} R$ throughout the first 2 postnatal weeks. $A$, Glutamatergic inputs to dorsal horn cells were elicited via electrical stimulation of the sciatic nerve and classified as monosynaptic on observing a constant latency and absence of synaptic failures with $10 \mathrm{~Hz}$ stimulation. Example illustrates an EPSC in a P14 neuron evoked at a threshold ( $300 \mu \mathrm{A}, 100 \mu \mathrm{sec}$ ) and latency (14.1 msec; approximate conduction velocity of $1.7 \mathrm{~m} / \mathrm{sec}$ ) suggestive of an input mediated by A $\delta$-fibers. Bath application of baclofen $(10 \mu \mathrm{m})$ resulted in a reversible block of the evoked EPSCS. B, The effect of baclofen on EPSC amplitude was prevented by previous treatment with the selective GABA $R$ antagonist CGP $55845(2 \mu \mathrm{M})$.C, Baclofen abolishes primary afferent-evoked EPSCs in all age groups (expressed as the percentage of baseline EPSC amplitude inhibited by baclofen). D, Baclofen (Bac) significantly reduces the frequency, but not the amplitude, of mEPSCs in dorsal horn neurons, consistent with a presynaptic site of action $\left({ }^{*} p<0.005\right.$; Wilcoxon matched-pairs test).

without a corresponding change in mEPSC amplitude strongly suggests a presynaptic site of action.

The effects of postsynaptic $\mathrm{GABA}_{\mathrm{B}} \mathrm{R}$ activation at different postnatal ages was investigated via bath application of baclofen $(100 \mu \mathrm{M})$ to dorsal horn neurons (using a $\mathrm{K}^{+}$-based electrode solution with $0.3 \mathrm{~mm} \mathrm{Na} \mathrm{N}_{3} \mathrm{GTP}$ substituted for GDP $\beta S$ ) and measuring the resulting change in holding current, which reflects the opening of GIRKs. An example of the slow outward current induced by baclofen (from $V_{\mathrm{h}}$ of $-60 \mathrm{mV}$ ) is illustrated in Figure $8 \mathrm{~A}$. Abolition of the baclofen effect by CGP $55845(2 \mu \mathrm{M})$ confirms that the outward current results from $\mathrm{GABA}_{\mathrm{B}}$ receptor activation (Fig. $8 \mathrm{~B}$ ). As illustrated in Figure

$8 C$, the amplitude of the $\mathrm{GABA}_{\mathrm{B}}$-mediated current depended on postnatal age, because the mean amplitude was significantly greater at P6-P7 $(40.0 \pm 8.7 \mathrm{pA} ; n=8 ; p<0.001 ;$ Kruskal-Wallis test $)$ and P13-P14 (17.21 $\pm 1.55 \mathrm{pA} ; n=11 ; p<0.01)$ than at $\mathrm{P} 0-\mathrm{P} 1(4.39 \pm 1.59 \mathrm{pA} ; n=12)$. Although current amplitudes appeared to peak at $\mathrm{P} 6-\mathrm{P} 7$ and subsequently decrease during the second postnatal week, there was no statistically significant difference between the mean amplitudes observed at P6-P7 and P13-P14 ( $p>0.05$; Kruskal-Wallis test). Similar results were seen when current amplitudes were normalized to cell capacitance to obtain measurements of current density at different ages (data not shown).

\section{Discussion}

Sensory networks in the immature spinal cord are characterized by a dependence on $\mathrm{GABA}_{\mathrm{A}} \mathrm{R}$ signaling, because GlyRs play an extremely limited role in spontaneous neurotransmission in the superficial dorsal horn during the first postnatal week (Figs. 2, 3). Functional dominance of $\mathrm{GABA}_{\mathrm{A}}$ receptors in developing spinal networks has been reported in motoneurons in which the frequency of $\mathrm{GABA}_{\mathrm{A}} \mathrm{R}$-mediated mIPSCs was fourfold higher than that of GlyR-mediated mIPSCs at embryonic day 17 (E17) to E18 (Gao et al., 2001). Dorsal horn neurons lacking GlyR-mediated sIPSCs responded to exogenous glycine applications, suggesting
B
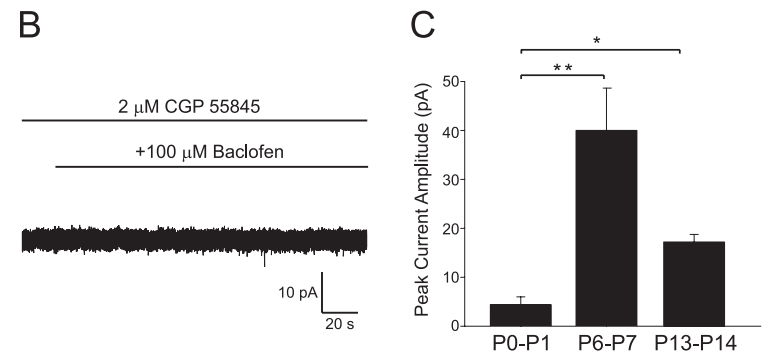

P0-P1 P6-P7 P13-P14

Figure 8. Effects of postsynaptic $G A B A_{B} R$ activation in dorsal horn neurons vary according to postnatal age. $A$, Bath application of the selective $G_{A B A_{B}} R$ agonist $R(+)$-baclofen hydrochloride elicits a slow outward current from a holding potential of $-60 \mathrm{mV}$ in neonatal dorsal horn cells. $B$, The effect of baclofen on the holding current was completely blocked by the selective $G_{A B A_{B}} R$ antagonist CGP $55845(2 \mu \mathrm{M})$. C, The amplitude of the baclofen-evoked outward current was significantly greater at P6 $-\mathrm{P7}$ and P13-P14 than at P0 ( ${ }^{*} p<0.01$; ${ }^{* *} p<0.001$; Kruskal-Wallis test).

the possibility that functional GlyRs have been inserted into the membrane by birth but have not yet clustered at synaptic sites. Synaptic localization of GlyRs in spinal neurons depends on the expression of gephyrin, which binds with high affinity to both GlyRs and the tubulin comprising the subsynaptic cytoskeleton (Kirsch et al., 1993). Gephyrin is also involved in the synaptic targeting of $\mathrm{GABA}_{\mathrm{A}}$ Rs containing the $\gamma 2$ or $\alpha 2$ subunits (Essrich et al., 1998; Kneussel et al., 1999) but is not required for stabilization of other $\mathrm{GABA}_{\mathrm{A}} \mathrm{R}$ subunits at inhibitory synapses (Kneussel et al., 2001). Interestingly, Dumoulin et al. (2000) report that $\mathrm{GABA}_{\mathrm{A}} \mathrm{Rs}$ accumulate at postsynaptic sites before gephyrin at inhibitory synapses in cultures of embryonic spinal neurons and suggest that $\mathrm{GABA}_{\mathrm{A}}$ Rs may be involved in the recruitment of gephyrin to synaptic loci (Dumoulin et al., 2000). An absence or low level of gephyrin expression in the neonatal dorsal horn during the first postnatal week could explain the observed dependence of sIPSCs on GABA Rs. $^{2}$.

In the adult superficial dorsal horn, approximately half of GABAergic neurons also express glycine (Todd and Sullivan, 1990), and the glycine transporter GLYT2 colocalizes with both known isoforms of the GABA synthetic enzyme glutamic acid decarboxylase in synaptic boutons (Mackie et al., 2003). Recent evidence suggests that GABA and glycine can be copackaged and released from the same presynaptic vesicles, resulting in mixed 
$\mathrm{GABA}_{\mathrm{A}} \mathrm{R}-\mathrm{GlyR}$ mIPSCs (Jonas et al., 1998; Keller et al., 2001). The expression of glycine and GABA transporters in the dorsal horn during early postnatal development has yet to be characterized. Although a failure to transport glycine from the extracellular space or into synaptic vesicles could explain the paucity of spontaneous GlyR currents in the P0-P7 dorsal horn, it seems unlikely because glycine is expressed in the dorsal horn by E8 (Berki et al., 1995) and is carried by the same vesicular transporter (VIAAT, for vesicular inhibitory amino acid transporter) as GABA (Gasnier, 2000).

Developmental changes in mIPSC kinetics have profound implications for the net synaptic inhibition of immature spinal neurons. Keller et al. (2001) described the kinetics of GABAergic and glycinergic mIPSCs in laminas I-II neurons between the ages of P8 and P23. GABA mIPSCs exhibited slower decay kinetics than Gly mIPSCs at all ages, with smaller differences seen in older neurons attributable to a fourfold increase in the GABA mIPSC decay rate during this period (Keller et al., 2001). Unfortunately, the very low frequency of GABA mIPSCs and absence of Gly mIPSCs at $\mathrm{P} 0-\mathrm{P} 1$, even in the presence of ruthenium red, meant that we could not compare the kinetics of GABA and Gly mIPSCs at birth. Additional experiments under conditions of elevated neurotransmitter release would be necessary to acquire enough events to accurately analyze mIPSC kinetics during the first postnatal days.

In many regions of the immature $\mathrm{CNS}, \mathrm{GABA}_{\mathrm{A}} \mathrm{R}$ activation causes membrane depolarization that is sufficient to elicit APs, because elevated levels of intracellular $\left[\mathrm{Cl}^{-}\right.$] yield an $E_{\mathrm{Cl}}$ that is more positive than both the resting potential and AP threshold (Leinekugel et al., 1997; Gao and van den Pol, 2001; Staley and Smith, 2001). In the developing hippocampus, GABAergic synapses form before glutamatergic inputs on CA1 pyramidal cells (Ben Ari et al., 1989) and interneurons (Hennou et al., 2002) and provide the main excitatory drive to the network as spontaneous activity was abolished by bicuculline (Ben Ari et al., 1989). A decrease in $[\mathrm{Cl}]_{\mathrm{i}}$ over the postnatal period resulting from the expression of the $\mathrm{K}^{+}-\mathrm{Cl}^{-}$cotransporter $\mathrm{KCC} 2$ can lead to a negative shift in $E_{\mathrm{Cl}}$, thus causing the effects of GABA and glycine to become progressively inhibitory (Owens et al., 1996; Rohrbough and Spitzer, 1996; Ehrlich et al., 1999; Rivera et al., 1999). GABAergic activity may itself promote the switch from synaptic excitation to inhibition in hippocampal neurons, because chronic blockade of $\mathrm{GABA}_{\mathrm{A}}$ receptors reduced the levels of KCC2 mRNA and delayed the onset of inhibition (Ganguly et al., 2001).

It is unlikely that the reported hyperexcitability of dorsal horn neurons during the first postnatal week (Fitzgerald and Jennings, 1999) results from a dominant excitatory role for GABA during early postnatal development. First, the distinct electrophysiological properties of immature dorsal horn neurons persist after the maturation of the $\mathrm{GABA}_{\mathrm{A}} \mathrm{R}$ response at the end of the first postnatal week. For example, at P6 A-fiber-induced sensitization of dorsal horn neurons is still widespread (33\% of cells compared with $0 \%$ at P21), and receptive fields remain large, corresponding to $36 \pm 2.9 \%$ of the total hindpaw area (Fitzgerald and Jennings, 1999), despite the exclusively hyperpolarizing action of GABA at this age (Fig. 5). More importantly, the present data show that $E_{\mathrm{GABA}}$ is consistently below AP threshold at birth (Fig. 6). This suggests that GABA-evoked depolarizations likely function to inhibit the firing of newborn dorsal horn neurons by clamping $V_{\mathrm{m}}$ to $E_{\mathrm{Cl}}$, thereby shunting subsequent EPSPs via an increase in membrane conductance and enhanced inactivation of voltagegated $\mathrm{Na}^{+}$channels (Bormann et al., 1987). Previous work has shown that GABA depolarizes embryonic and early postnatal motoneurons but still blocks AP discharge, suggesting that GABAergic synaptic inhibition is functional by E18.5 in the ventral horn (Hubner et al., 2001; Marchetti et al., 2002), consistent with the widespread expression of KCC2 in the spinal cord by this age (Hubner et al., 2001). The heterogeneity of GABA responses observed in the present study (Fig. 5C) suggests considerable diversity in KCC2 levels among individual superficial dorsal horn neurons at birth. Overall, the present data suggest that, in contrast to the hippocampus, $\mathrm{GABA}_{\mathrm{A}}$ Rs do not provide the main excitatory drive to the network in the newborn dorsal horn. It should be noted that these results do not exclude a transient excitatory role for GABA in the developing dorsal horn. Indeed, single-channel recordings of GABA-activated $\mathrm{Cl}^{-}$channels in embryonic (E15) spinal cord neurons have reported an approximate $E_{\mathrm{GABA}}$ of $-30 \mathrm{mV}$ (Serafini et al., 1995). Our results instead suggest that the switch from excitation to inhibition begins during the embryonic period and appears complete by the end of the first postnatal week.

The presence of depolarizing, inhibitory $\mathrm{GABA}_{\mathrm{A}} \mathrm{R}$ potentials in the neonatal superficial dorsal horn may promote $\mathrm{Ca}^{2+}$ entry into neurons without allowing unchecked excitation during a period in which primary afferent $C$-fiber synaptic inputs are rapidly strengthening (Baccei et al., 2003) and descending inhibitory systems are not yet functional (Fitzgerald and Koltzenburg, 1986). Previous reports have demonstrated that $G_{A B A} R-$ evoked depolarizations increase $\left[\mathrm{Ca}^{2+}\right]_{\mathrm{i}}$ via activation of $\mathrm{N}$-type and L-type voltage-gated calcium channels in embryonic dorsal horn neurons (Reichling et al., 1994). These depolarizations may also contribute to the relief of the $\mathrm{Mg}^{2+}$ block of NMDA receptors (Khazipov et al., 1997), further increasing calcium influx into newborn dorsal horn neurons. Such elevations of intracellular calcium levels may be important for various developmental processes, including synapse formation and remodeling, as well as neuronal differentiation (Wang et al., 1994; Ben Ari, 2002). Thus, at birth, $\mathrm{GABA}_{\mathrm{A}} \mathrm{R}$ activation may facilitate the maturation of the dorsal horn network despite preventing AP discharge in dorsal horn neurons.

Presynaptic modulation of glutamatergic transmission by $\mathrm{GABA}_{\mathrm{B}} \mathrm{Rs}$ is observed at birth in CA1 hippocampal neurons, but postsynaptic $\mathrm{GABA}_{\mathrm{B}} \mathrm{R}$-mediated inhibition is absent (Gaiarsa et al., 1995). The present results suggest that both presynaptic and postsynaptic $\mathrm{GABA}_{\mathrm{B}} \mathrm{Rs}$ in the superficial dorsal horn are functional at birth but are regulated differently over the early postnatal period (Figs. 7, 8). Presynaptic inhibition of primary afferentevoked EPSCs by baclofen has been reported previously in the neonatal dorsal horn (Blake et al., 1993), and the present study demonstrates that it remains potent throughout the first 2 postnatal weeks. Meanwhile, postsynaptic $\mathrm{GABA}_{\mathrm{B}} \mathrm{R}$ effects depended on postnatal age with maximal outward currents seen by $\mathrm{P} 6-\mathrm{P} 7$. Recent work has identified three subunits $\left(G_{A B A} R 1 a, G A B A_{B} R 1 b\right.$, and $\mathrm{GABA}_{\mathrm{B}} \mathrm{R} 2$ ) that heterodimerize to form functional $\mathrm{GABA}_{\mathrm{B}} \mathrm{Rs}$ (White et al., 1998; Kuner et al., 1999) and are expressed in the DRG and superficial dorsal horn, with $\mathrm{GABA}_{\mathrm{B}} \mathrm{R}$ la preferentially localized on presynaptic terminals and $\mathrm{GABA}_{\mathrm{B}} \mathrm{R} 1 \mathrm{~b}$ on cell bodies in the region (Towers et al., 2000). Developmental changes in the expression of $\mathrm{GABA}_{\mathrm{B}} \mathrm{R} 1 \mathrm{~b}$ (or $\mathrm{GABA}_{\mathrm{B}} \mathrm{R} 2$ ) subunits, or postnatal regulation of downstream GIRKs (Chen et al., 1997), could account for the agerelated differences in postsynaptic $\mathrm{GABA}_{\mathrm{B}} \mathrm{R}$ effects. Additional experiments are necessary to determine whether the synaptic activation of presynaptic and postsynaptic $\mathrm{GABA}_{\mathrm{B}}$ Rs varies as a function of age.

Additional investigation of the synaptic and intrinsic properties of neonatal dorsal horn neurons will help elucidate possible 
mechanisms underlying the lower reflex thresholds and enlarged receptive fields that characterize the immature spinal cord. Clearly, the patterns of inhibitory activity in the superficial dorsal horn, essential to the sensory processing of painful stimuli, are modified during the early postnatal period.

\section{References}

Akaike N (1996) Gramicidin perforated patch recording and intracellular chloride activity in excitable cells. Prog Biophys Mol Biol 65:251-264.

Andrews K, Fitzgerald M (1994) The cutaneous withdrawal reflex in human neonates: sensitization, receptive fields, and the effects of contralateral stimulation. Pain 56:95-101.

Baccei ML, Bardoni R, Fitzgerald M (2003) Development of nociceptive synaptic inputs to the neonatal rat dorsal horn: glutamate release by capsaicin and menthol. J Physiol (Lond) 549:231-242.

Ben Ari Y (2002) Excitatory actions of gaba during development: the nature of the nurture. Nat Rev Neurosci 3:728-739.

Ben Ari Y, Cherubini E, Corradetti R, Gaiarsa JL (1989) Giant synaptic potentials in immature rat CA3 hippocampal neurones. J Physiol (Lond) 416:303-325.

Berki AC, O’Donovan MJ, Antal M (1995) Developmental expression of glycine immunoreactivity and its colocalization with GABA in the embryonic chick lumbosacral spinal cord. J Comp Neurol 362:583-596.

Blake JF, Cao CQ, Headley PM, Collingridge GL, Brugger F, Evans RH (1993) Antagonism of baclofen-induced depression of whole-cell synaptic currents in spinal dorsal horn neurones by the potent GABAB antagonist CGP55845. Neuropharmacology 32:1437-1440.

Bormann J (1988) Electrophysiology of GABAA and GABAB receptor subtypes. Trends Neurosci 11:112-116.

Bormann J, Hamill OP, Sakmann B (1987) Mechanism of anion permeation through channels gated by glycine and gamma-aminobutyric acid in mouse cultured spinal neurones. J Physiol (Lond) 385:243-286.

Chen G, Trombley PQ, van den Pol AN (1996) Excitatory actions of GABA in developing rat hypothalamic neurones. J Physiol (Lond) 494:451-464.

Chen SC, Ehrhard P, Goldowitz D, Smeyne RJ (1997) Developmental expression of the GIRK family of inward rectifying potassium channels: implications for abnormalities in the weaver mutant mouse. Brain Res 778:251-264.

Dumoulin A, Levi S, Riveau B, Gasnier B, Triller A (2000) Formation of mixed glycine and GABAergic synapses in cultured spinal cord neurons. Eur J Neurosci 12:3883-3892.

Ehrlich I, Lohrke S, Friauf E (1999) Shift from depolarizing to hyperpolarizing glycine action in rat auditory neurones is due to age-dependent $\mathrm{Cl}^{-}$ regulation. J Physiol (Lond) 520:121-137.

Essrich C, Lorez M, Benson JA, Fritschy JM, Luscher B (1998) Postsynaptic clustering of major GABAA receptor subtypes requires the gamma 2 subunit and gephyrin. Nat Neurosci 1:563-571.

Fitzgerald M (1985) The post-natal development of cutaneous afferent fibre input and receptive field organization in the rat dorsal horn. J Physiol (Lond) 364:1-18.

Fitzgerald M, Jennings E (1999) The postnatal development of spinal sensory processing. Proc Natl Acad Sci USA 96:7719-7722.

Fitzgerald M, Koltzenburg M (1986) The functional development of descending inhibitory pathways in the dorsolateral funiculus of the newborn rat spinal cord. Brain Res 389:261-270.

Gaiarsa JL, Tseeb V, Ben Ari Y (1995) Postnatal development of pre- and postsynaptic GABAB-mediated inhibitions in the CA3 hippocampal region of the rat. J Neurophysiol 73:246-255.

Ganguly K, Schinder AF, Wong ST, Poo M (2001) GABA itself promotes the developmental switch of neuronal GABAergic responses from excitation to inhibition. Cell 105:521-532.

Gao BX, Stricker C, Ziskind-Conhaim L (2001) Transition from GABAergic to glycinergic synaptic transmission in newly formed spinal networks. J Neurophysiol 86:492-502.

Gao XB, van den Pol AN (2001) GABA, not glutamate, a primary transmitter driving action potentials in developing hypothalamic neurons. J Neurophysiol 85:425-434.

Gasnier B (2000) The loading of neurotransmitters into synaptic vesicles. Biochimie 82:327-337.
Hennou S, Khalilov I, Diabira D, Ben Ari Y, Gozlan H (2002) Early sequential formation of functional GABA(A) and glutamatergic synapses on CA1 interneurons of the rat foetal hippocampus. Eur J Neurosci 16:197-208.

Hubner CA, Stein V, Hermans-Borgmeyer I, Meyer T, Ballanyi K, Jentsch TJ (2001) Disruption of KCC2 reveals an essential role of K-Cl cotransport already in early synaptic inhibition. Neuron 30:515-524.

Jonas P, Bischofberger J, Sandkuhler J (1998) Corelease of two fast neurotransmitters at a central synapse. Science 281:419-424.

Keller AF, Coull JA, Chery N, Poisbeau P, De Koninck Y (2001) Regionspecific developmental specialization of GABA-glycine cosynapses in laminas I-II of the rat spinal dorsal horn. J Neurosci 21:7871-7880.

Khazipov R, Leinekugel X, Khalilov I, Gaiarsa JL, Ben Ari Y (1997) Synchronization of GABAergic interneuronal network in CA3 subfield of neonatal rat hippocampal slices. J Physiol (Lond) 498:763-772.

Kirsch J, Wolters I, Triller A, Betz H (1993) Gephyrin antisense oligonucleotides prevent glycine receptor clustering in spinal neurons. Nature 366:745-748.

Kneussel M, Brandstatter JH, Laube B, Stahl S, Muller U, Betz H (1999) Loss of postsynaptic $\mathrm{GABA}_{\mathrm{A}}$ receptor clustering in gephyrin-deficient mice. J Neurosci 19:9289-9297.

Kneussel M, Brandstatter JH, Gasnier B, Feng G, Sanes JR, Betz H (2001) Gephyrin-independent clustering of postsynaptic GABA(A) receptor subtypes. Mol Cell Neurosci 17:973-982.

Kuner R, Kohr G, Grunewald S, Eisenhardt G, Bach A, Kornau HC (1999) Role of heteromer formation in GABAB receptor function. Science 283:74-77.

Kyrozis A, Reichling DB (1995) Perforated-patch recording with gramicidin avoids artifactual changes in intracellular chloride concentration. J Neurosci Methods 57:27-35.

Leinekugel X, Medina I, Khalilov I, Ben Ari Y, Khazipov R (1997) $\mathrm{Ca}^{2+}$ oscillations mediated by the synergistic excitatory actions of GABA(A) and NMDA receptors in the neonatal hippocampus. Neuron 18:243-255.

Mackie M, Hughes DI, Maxwell DJ, Tillakaratne NJ, Todd AJ (2003) Distribution and colocalisation of glutamate decarboxylase isoforms in the rat spinal cord. Neuroscience 119:461-472.

Marchetti C, Pagnotta S, Donato R, Nistri A (2002) Inhibition of spinal or hypoglossal motoneurons of the newborn rat by glycine or GABA. Eur J Neurosci 15:975-983.

Moore KA, Kohno T, Karchewski LA, Scholz J, Baba H, Woolf CJ (2002) Partial peripheral nerve injury promotes a selective loss of GABAergic inhibition in the superficial dorsal horn of the spinal cord. J Neurosci 22:6724-6731.

Owens DF, Kriegstein AR (2002) Is there more to gaba than synaptic inhibition? Nat Rev Neurosci 3:715-727.

Owens DF, Boyce LH, Davis MB, Kriegstein AR (1996) Excitatory GABA responses in embryonic and neonatal cortical slices demonstrated by gramicidin perforated-patch recordings and calcium imaging. J Neurosci 16:6414-6423.

Reichling DB, Kyrozis A, Wang J, MacDermott AB (1994) Mechanisms of GABA and glycine depolarization-induced calcium transients in rat dorsal horn neurons. J Physiol (Lond) 476:411-421.

Rivera C, Voipio J, Payne JA, Ruusuvuori E, Lahtinen H, Lamsa K, Pirvola U, Saarma M, Kaila K (1999) The $\mathrm{K}^{+} / \mathrm{Cl}^{-}$co-transporter KCC2 renders GABA hyperpolarizing during neuronal maturation. Nature 397:251-255.

Rohrbough J, Spitzer NC (1996) Regulation of intracellular $\mathrm{Cl}^{-}$levels by $\mathrm{Na}^{+}$-dependent $\mathrm{Cl}^{-}$cotransport distinguishes depolarizing from hyperpolarizing $\mathrm{GABA}_{\mathrm{A}}$ receptor-mediated responses in spinal neurons. J Neurosci 16:82-91.

Serafini R, Valeyev AY, Barker JL, Poulter MO (1995) Depolarizing GABAactivated $\mathrm{Cl}^{-}$channels in embryonic rat spinal and olfactory bulb cells. J Physiol (Lond) 488:371-386.

Staley K, Smith R (2001) A new form of feedback at the GABA(A) receptor. Nat Neurosci 4:674-676.

Todd AJ, Spike RC (1993) The localization of classical transmitters and neuropeptides within neurons in laminae I-III of the mammalian spinal dorsal horn. Prog Neurobiol 41:609-645.

Todd AJ, Sullivan AC (1990) Light microscope study of the coexistence of 
GABA-like and glycine-like immunoreactivities in the spinal cord of the rat. J Comp Neurol 296:496-505.

Torsney C, Fitzgerald M (2002) Age-dependent effects of peripheral inflammation on the electrophysiological properties of neonatal rat dorsal horn neurons. J Neurophysiol 87:1311-1317.

Towers S, Princivalle A, Billinton A, Edmunds M, Bettler B, Urban L, CastroLopes J, Bowery NG (2000) GABAB receptor protein and mRNA distribution in rat spinal cord and dorsal root ganglia. Eur J Neurosci 12:3201-3210.

Trudeau LE, Doyle RT, Emery DG, Haydon PG (1996) Calciumindependent activation of the secretory apparatus by ruthenium red in hippocampal neurons: a new tool to assess modulation of presynaptic function. J Neurosci 16:46-54.

Tyzio R, Ivanov A, Bernard C, Holmes GL, Ben Ari Y, Khazipov R (2003)
Membrane potential of CA3 hippocampal pyramidal cells during postnatal development. J Neurophysiol 90:2964-2972.

Wang J, Reichling DB, Kyrozis A, MacDermott AB (1994) Developmental loss of GABA- and glycine-induced depolarization and $\mathrm{Ca}^{2+}$ transients in embryonic rat dorsal horn neurons in culture. Eur J Neurosci 6:1275-1280

White JH, Wise A, Main MJ, Green A, Fraser NJ, Disney GH, Barnes AA, Emson P, Foord SM, Marshall FH (1998) Heterodimerization is required for the formation of a functional GABA(B) receptor. Nature 396:679-682.

Yoshimura M, Nishi S (1993) Blind patch-clamp recordings from substantia gelatinosa neurons in adult rat spinal cord slices: pharmacological properties of synaptic currents. Neuroscience 53:519-526. 